Temos aqui condições cada vez mais semelhantes às de outros países para massacres nas escolas

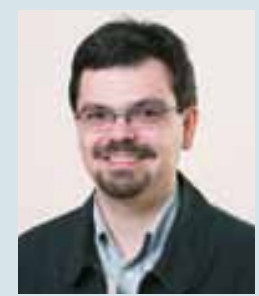

LUIS GALEÃO, USP - Instituto de Psicologia, luisgaleao@usp.br

\title{
VIOLÊNCIA E ANGÚSTIA NO CAMPO DA EDUCAÇÃO
}

0 massacre na escola de Realengo parece ter sido há muito tempo, possivelmente desapareceu da mídia devido à sucessão de grandes tragédias, mas ocorreu há pouco menos de um ano, em 2011. Não vamos fazer uma análise a distância sem conhecer as pessoas envolvidas e seu contexto específico, mas podemos tomar a tragédia como ponto de partida de uma reflexão sobre as angústias de jovens e de educadores nas cidades brasileiras.

Coordenei, por alguns anos, o atendimento psicológico aos jovens universitários da FGVEAESP. Em 2003, esse programa estabeleceu um contrato com um grupo de psicólogos e psiquiatras que realizavam, desde então, diagnósticos e apoios breves aos alunos de graduação. É um serviço multidisciplinar que pretende contribuir com a educação dos jovens, na medida em que permite um tipo de diálogo terapêutico para aprenderem a lidar com suas emoções e dilemas. Essa escuta fazia parte de uma estrutura de apoio que, durante o período inicial, incluía professores tutores encarregados de acompanhar os primeiros passos dos jovens na faculdade.

Em uma sexta-feira, o educador e tutor de uma turma nos procurou preocupado: soubera que um aluno traria uma arma na segunda-feira e atiraria em um colega. Perguntávamo-nos como proceder com tal informação. Caso fosse um alarme falso, poderíamos ter uma reação maior do que o necessário, agindo com base em uma fala de terceiros. Por outro lado, seríamos responsáveis, sabendo da ameaça, por qualquer agressão que houvesse naquela segunda-feira. Para tranquilidade de todos, o professor conseguiu conversar com o suposto agressor e o problema foi contornado, evitando uma agressão mais séria naquele dia.

Imaginamos qual seria a angústia dos alunos envolvidos. Os alunos eram colegas de classe, se conheciam, o que, aliás, é uma característica comum de crimes de homicídio na cidade de São Paulo. O ameaçado estaria na iminência de uma grave agressão e teria alguma ideia de como chegara a isso? Perguntávamo-nos sobre o que ocorrera para haver uma ameaça como aquela. Estávamos muito tensos, mas não surpresos, com a situação. Entendemos que hoje existe a aflitiva espera de uma situação assim para jovens e educadores.

Um conceito que nos ajuda a compreender essa angústia de jovens e educadores pode ser encontrado no ensaio Educação após Auschwitz, do filósofo Theodor Adorno. Na escola e na sociedade, os "esforços por fomentar laços sociais mais fortes para evitar a agressão bárbara tendem ao fracasso". Esses esforços por relações verdadeiras e solidárias são minados por tendências poderosas à frieza das relações. No Brasil, o suposto calor das relações interpessoais não evita a tendência à frieza nas relações com base no uso do outro como instrumento ou no estereótipo desqualificador (por exemplo: pobre, perdedor, negro etc.). A mudança dar-se-ia por uma forte reflexão coletiva e crítica a respeito da barbárie e da frieza em nossa sociedade. Temos aqui condições cada vez mais semelhantes às de outros países para massacres nas escolas, com o agravante de que já vivemos em um país com um enorme número de homicídios de jovens.

Por esse motivo, entendo que há poucos casos como Realengo e muitos outros casos, menos espetaculares, de agressões a jovens e entre jovens. Existe um temor fundamentado e geral de que a agressão irrompa no nosso cotidiano, mas, no lugar de o evitarmos, contribuímos para esse quadro, no lugar de dar voz às angústias de educadores e jovens, apresentamos técnicas inúteis de convívio e reforço dos laços sociais. 